\title{
ASSESSMENT OF GROUNDWATER QUALITY OF TEHSIL BAH, AGRA DISTRICT (U.P) - A REVIEW
}

\author{
Ajay Sharma ${ }^{1}$, and B. Rupini ${ }^{2 *}$ \\ School of Inter-Disciplinary and Trans-Disciplinary Studies (SOITS) \\ First Floor EMPC, Indira Gandhi National Open University, Maidan Garhi New Delhi - 110068
}

\section{Research Article}

Received: 15.05.2021

Accepted: 22.05.2021

Published: 12.06.2021

\begin{abstract}
Groundwater is an important source for drinking, Agriculture, domestic and industrial purposes and makes about two third of the freshwater resource of the world. The quality and quantity of the groundwater is a serious concern for the India as eighteen percentage of world population live in India and just $4 \%$ of world fresh water availability in India. Quality of groundwater is a serious concern for mankind as it is directly linked to human health. Due to the rapid increase in the population in last four decades makes a big challenge to provide quality of water. Industrialization and other manmade activities are also contributing in decline trained of groundwater. The groundwater is being polluted with highly toxic contaminants such as arsenic, fluoride, nitrate, chloride, fluoride, lead and heavy metals. Fluoride and chloride were found as most common contaminants in Agra region. Fluoride and chloride are coming into the groundwater from deep underground rocks bearing fluorine and chlorine. Geological structure of rocks is also responsible for Fluoride and chloride pollution in the groundwater of the region. Major groundwater problems in Agra region are a significant decline in water level, an occurrence of fluoride, saline groundwater in a deeper zone, less groundwater recharge and more surface runoff of monsoon rainfall. The comparison of analyzed ground water samples with the WHO, APHA standards are presented. The study was concluded by over exploitation of groundwater for the drinking, domestic, irrigation purposes and the leaching of industrial wastes and municipal solid waste (MSW) is one of the leading emerging sources of contamination of groundwater in Agra region.
\end{abstract}

Keywords: Groundwater, Agra Region \& Contaminants.

\section{INTRODUCTION}

World is facing fresh water crisis and its posing threat to world sustainable growth, India has just $4 \%$ of the world's fresh water and around $18 \%$ of the world population live in India. We have witnessed the water crisis in the city of Cape town, south Africa and similar crisis in Chennai, Shimla, Bundelkhand in up and part of the Maharashtra. Part of assessment of quality of ground water Agarwal Et al. studied on nitrate and other contaminants in the groundwater of Gautam Budh Nagar District of UP, India in which $95.4 \%$ of collected groundwater samples are not meeting the requirement of Bureau of Indian standard (IS 10500:2012) [1]. All the samples were tested as per the method is given by the American Public Health Association
(APHA, 23rd Edn.2017). 2.Sharma Et al. studied fluoride concentration in groundwater of Baroli aheer area of Agra district and found $71 \%$ of the samples in the study are having fluoride concentration more than $1.5 \mathrm{mg} / \mathrm{l}$. Fluoride in groundwater of this area is mainly due to fluoridebearing minerals, Similar study of the shallow aquifers of Marks Nagar, Unnao district of Uttar Pradesh, water is highly contaminated with fluoride concentration, Health hazard (Fluorosis) detected in human population and infestations have also been noticed in cattle. Around 87.5\% of collected water samples were exceeding permissible limit of $1.5 \mathrm{mg} / \mathrm{l}$ as prescribed by bureau of Indian standard and another Study on groundwater quality Kheragarh Tehsil of Agra district with special reference to the Fluoride

*Corresponding author: brupini@ignou.ac.in 
concentration, the range of fluoride concentration was found from $0.11 \mathrm{mg} / \mathrm{l}$ to $12.8 \mathrm{mg} / \mathrm{l}$. It is observed that about $73 \%$ of fluoride samples, $80 \%$ of $\mathrm{pH}$ samples, $82 \%$ of total hardness samples, $88 \%$ of total alkalinity samples, $48 \%$ of chloride samples, $64 \%$ of calcium samples and $99 \%$ of magnesium samples were not meeting the requirement of IS 10500 (1990) [2]. Physico chemical characteristics of groundwater of Agra city were studies by analysing samples from 12 different sites of the Agra city and found that water is not meeting the requirement of Bureau of Indian standard and WHO standard, Precautionary measures were recommended before drinking to prevent adverse health impacts to citizen of the region [3]. A study of the shallow aquifers of Marks Nagar, Unnao district of Uttar Pradesh revealed that high concentration of fluoride and consequent health hazard (Fluorosis) and infestations detected in human population and in cattle. Samples were collected from shallow hand pumps and dug wells, the only available source for drinking and domestic purposes, around $87.5 \%$ of collected water samples were exceeding permissible limit of $1.5 \mathrm{mg} / \mathrm{l}$ as prescribed by Bureau of Indian Standard (BIS) [4]. The ground water quality studies shows that conductivity is an important physicochemical water quality parameter having correlation with conductivity are temperature, $\mathrm{pH}$, alkalinity, total hardness, calcium, total solids, Total Dissolved Solids (TDS), Chemical Oxygen Demand (COD), chloride ion and iron in water [5]. The investigations on the iron contamination in groundwater at Tangail municipality of Bangladesh shows a link between $\mathrm{pH}$ and iron concentration. Lower value of $\mathrm{pH}$ in collected samples are have higher value of iron concentration, which is evident that $\mathrm{pH}$ is indirectly proportionate to iron concentration. All these calculated measurements were exceeded the prescribed limit for iron given by WHO, Indian standard and Bangladesh standard [6]. Research studies on pollution by leachate from a waste management site in southwestern Bangalore city which causes toxic surface water and groundwater contamination. Groundwater quality samples were analyzed from 20 stations from the vicinity of the Haralukunte lake for their physicochemical quality of water, revealed that there is a significant evidence for high degree of pollution and is not fit for drinking purposes [7]. In another research results found major groundwater problems in Agra are a significant decline in water level, an occurrence of Fluoride, Saline ground water in a deeper zone, less groundwater recharge and more surface runoff of monsoon rainfall. Majority of the district is having alluvial plains. About $70 \%$ of the area is under agriculture use and surface water such as canal water and groundwater are being used for irrigation purposes [8]. Research Studies on heavy metal concentration in drinking water with respect to Zinc, copper, cadmium, manganese, lead and arsenic in Kamrup district of Assam, shows that excess concentration of $\mathrm{Cd}, \mathrm{Mn}$, and $\mathrm{Pb}$ present at some locations and it making water not fit for drinking purposes [9]. Fluoride, boron and nitrate concentration in groundwater of different villages in Indira Gandhi, Bhakra and Gang canal catchment area of northwest Rajasthan were analyzed by adopting established methodologies. Fluoride is analyzed by SPADNS method, boron was tested by colorimetric method using carmine as the color developing agent and nitrate was estimated by phenol di sulphonic acid method. $81.67 \%$ of fluoride samples were exceeding the prescribed limit of fluoride, $34 \%$ of boron samples were found with the high concentration of boron and 300 water samples were tested for nitrate in which 97.33\% samples were observed within the prescribed range and $2.33 \%$ were observed out of prescribed range i.e. $45 \mathrm{mg} / \mathrm{l}[10]$.

Gupta Et al Studied groundwater quality with special reference to the Fluoride concentration from 261 villages of Kheragarh Tehsil of Agra district. the range of fluoride concentration was found from $0.11 \mathrm{mg} / \mathrm{l}$ to $12.8 \mathrm{mg} / \mathrm{l}$. It is observed that about $73 \%$ of fluoride samples, $80 \%$ of $\mathrm{pH}$ samples, $82 \%$ of total hardness samples, $88 \%$ of total alkalinity samples, $48 \%$ of chloride samples, $64 \%$ of calcium samples and $99 \%$ of magnesium samples were not meeting the requirement of Bureau of Indian Standard i.e. IS 10500 (1990). Piped water supply is proposed to the residents for drinking and other cooking purposes [11]. Water quality index is established with the help of various physico-chemical parameters in different seasons. Water quality index for rainy season, winter season and summer season are 96, 101.7 and 106.3 respectively, it indicates poor quality of water (Chatterji and Raziuddin 2002). The water quality rating study shows that it is not suitable for human uses. It is also observed that water body is suffering with relatively high load of pollution in summer season compared to winter and rainy season [12]. Water quality index with reference to chloride, the electrical conductivity indicating poor ground water quality of the study area. Sodium 
Absorption Ratio (SAR) shows significant high percentage of sodium in most of the study locations, indicating ground water quality is not suitable for irrigation purposes. [13] Physico chemical parameters of tap water of Chandigarh, was measured by the testing against parameters like color, odor, temperature, $\mathrm{pH}$, Turbidity, Electrical conductivity, Total dissolved solids, Dissolved oxygen and salinity. Results of the parameters were found well within the limit prescribed by Bureau of Indian standard and World Health Organization (BIS/WHO).[14] Heavy metals such as $\mathrm{Cd}, \mathrm{Cr}, \mathrm{Cu}, \mathrm{Fe}, \mathrm{Hg}, \mathrm{Mn}, \mathrm{Ni}, \mathrm{Pb}$, and $\mathrm{Zn}$ in 39 water supplying wells 5 water storage tank in which iron was reported higher than standard in 03 wells, high concentration of iron in ground water in the city of Bafgh and Ardakan and it was found that due to industrial activities of iron extraction and its processing such as pelletizing and rolling would be the root cause of contamination. The sludge and effluent flowing from sewage treatment plant is also being released in to environment.[15] The physico-chemical analysis of groundwater was conducted for the villages of Kadi tehsil at Mehsana district of Gujarat where ground water is the only source of drinking water in most of the villages. There was a positive correlation observed between $\mathrm{pH}$ and fluoride in ground water which indicates high alkaline nature of the water promotes leaching of fluoride ion and affect the concentration of fluoride in ground water. A negative relationship was observed between the $\mathrm{pH}$ and bicarbonate which is generally found in deeper zone of groundwater and positive relationship was observed in shallow groundwater. [16] In another research study conducted to estimate the current status of Pus dam of Pusad Tehsil of Yavatmal district, Maharashtra, reveals that there is no harmful contaminant for pisciculture, irrigation and drinking water. There was positive correlation found with temperature and $\mathrm{pH}$, TDS, total hardness, chloride, phosphate, BOD. The transparency has been found with positive correlation with chloride, dissolved oxygen and biological oxygen demand while nitrate negatively correlated with transparency.[17] Ground water from 53 open wells in Sangamner area of Ahmednagar was analyzed, the results showed higher values which are close to river channel and downstream of the river of Pravara. Dominant cations are calcium and magnesium followed by sodium, predominant anions are chloride followed by bicarbonate, sulphate and nitrate ions. Study also reveals that intensive irrigation has a serious impact on the quality of water of the area, which is suggested that excessive use of fertilizers and irrigation caused deterioration of groundwater quality. The remedial measures like controlled use of fertilizers and mixed culture of cropping pattern will help for sustainable agriculture and water use planning.[18] Various research studies of the assessment of water quality were reviewed for physico-chemical parameters and iron. It was found that water pollution is not only devastating to people, but also destroying animals, plants and flora and fauna of aquatic life and reduces its reproductive ability. The sustainable practice suggest that individual and community can help to minimize the water pollution by adopting good management practices and housekeeping to ensure lesser amount of waste water generated. The present study focused on the assessment of ground water quality of some places in Tehsil Bah, Uttar Pradesh, India.

\section{Present Study}

The Agra district is located in the western part of Uttar Pradesh and universally renowned place because of Taj Mahal. The quality of water is serious concern for mankind as it is directly linked with human health and common man. The groundwater makes about two third of the freshwater resource of the world. Majority of rural population (85\%) depend on groundwater for drinking purposes and domestic uses. Due to rapid increase in the population, industrialization and other man-made activities, the groundwater is being polluted with highly toxic contaminants. Groundwater of Agra region is contaminated with salinity, Fluoride, Chloride, Nitrate and Arsenic. Baroli Ahir area of Agra district and Kheragarh area of Agra district were found high concentration of fluoride i.e., more than $1.5 \mathrm{mg} / \mathrm{l}$ (prescribed by IS: 10500:2012) and fluoride is coming to the groundwater from fluoride bearing rocks.

Leaching of industrial waste and municipal solid waste (MSW), Use of chemical fertilizer and pesticides are one of the emerging sources of contamination for ground water quality. Groundwater may have many substances in the form of solution or suspension. Calcium, magnesium, sodium, potassium, iron, cobalt, zinc, copper, chloride, nitrate, fluoride, sulfate, arsenic, pesticides and a variety of other substances may find in different concentration in the groundwater. About 70\% groundwater used for irrigation purposes is having serious impacts on quantity and quality of groundwater, uses of water for irrigation is required to minimized by adopting scientific approach during irrigation. 
Scarcity and declining trends of groundwater is imposing high level of risk to the gross domestic products (GDP) specially energy sector, Thermal energy is the main source of the country, thermal power plants in the country are facing shortage of water during summer and other seasons another sector that is micro, small and medium enterprises (MSME) is also hampered to its production and supply chain of goods and services. Scarcity or declining trends of groundwater may dilute our goal of self-reliant Bharat. Quality of water is utmost required to minimize the health risk, that should meet the standard limit prescribed by national and international bodies such as BIS, WHO, EN etc.

Providing good quality of water for drinking purpose to rising population of the world is extra burden on the water resources and a challenge to entire world to meet the quality of water for domestic, industrial, agricultural and other purposes resulted in unsustainable practices of water conservation from natural resources.

In India, Groundwater quality is depleting with reference to the presence of contaminants above the acceptable limits. Some major reasons of groundwater contamination are as following:

(I) The difference between pumping of groundwater and recharge or replenish of groundwater.

(ii) Sewage and Domestic Wastes.

(iii) Industrial discharges.

(iv) Improper handling of MSW and medical wastes.

(v) Agricultural discharges (Pesticides and chemical fertilizers).

(vi) Thermal pollution.

\section{Physicochemical Parameters of Ground Water}

IS: 10500 (2012) is Indian standard for drinking water is formulated by bureau of Indian standard, in these standard limits are given as Acceptable Limit and Permissible Limit in the Absence of Alternative Source.[19] World health organization (WHO) is a global standard providing limits for drinking water internationally. The Requirement (Acceptable Limit) and Permissible Limit in the Absence of Alternative Source in accordance with IS 10500, 2012 is given in Table 1 to 3.

Drinking Water Standards limits in accordance with IS: 10500, 2012

Table 1:

\begin{tabular}{|l|l|l|l|l|}
\hline Sr. & $\begin{array}{l}\text { Organoleptic and } \\
\text { Physical Parameters }\end{array}$ & $\begin{array}{l}\text { Requirement } \\
\text { (Acceptable Limit) }\end{array}$ & $\begin{array}{l}\text { Permissible Limit in } \\
\text { the Absence of } \\
\text { Alternative Source }\end{array}$ & Unit \\
\hline 1. & Colour & 5 & 15 & Hazen \\
\hline 2. & Odour & Agreeable & Agreeable & NA \\
\hline 3. & pH value & $6.5-8.5$ & No Relaxation & NA \\
\hline 4. & Taste & Agreeable & Agreeable & NA \\
\hline 5. & Turbidity & 1 & 5 & NTU \\
\hline 6. & Total dissolved solids & 500 & 2000 & mg/l \\
\hline
\end{tabular}

Table 2:

\begin{tabular}{|l|l|l|l|l|}
\hline Sr. & $\begin{array}{l}\text { General Parameters } \\
\text { Concerning Substances } \\
\text { Undesirable in Excessive } \\
\text { Amounts }\end{array}$ & $\begin{array}{l}\text { Requirement } \\
\text { (Acceptable Limit) }\end{array}$ & $\begin{array}{l}\text { Permissible Limit in the } \\
\text { Absence of Alternative } \\
\text { Source }\end{array}$ & Unit \\
\hline 1. & Aluminium (as Al) & 0.03 & 0.2 & $\mathrm{mg} / \mathrm{l}$ \\
\hline 2. & Barium (as Ba) & 0.7 & No Relaxation & $\mathrm{mg} / \mathrm{l}$ \\
\hline 3. & Boron (as B) & 0.5 & 1 & $\mathrm{mg} / \mathrm{l}$ \\
\hline
\end{tabular}




\begin{tabular}{|l|l|l|l|l|}
\hline 4. & Calcium (as Ca) & 75 & 200 & $\mathrm{mg} / \mathrm{l}$ \\
\hline 5. & Chloramines (as Cl2) & 0.4 & No Relaxation & $\mathrm{mg} / \mathrm{l}$ \\
\hline 6. & Chloride (as Cl) & 250 & 1000 & $\mathrm{mg} / \mathrm{l}$ \\
\hline 7. & Copper (as Cu) & 0.05 & 1.5 & $\mathrm{mg} / \mathrm{l}$ \\
\hline 8. & Fluoride (as F) & 1.0 & 1.5 & $\mathrm{mg} / \mathrm{l}$ \\
\hline 9. & Iron (as Fe) & 0.3 & No Relaxation & $\mathrm{mg} / \mathrm{l}$ \\
\hline 10. & Magnesium (as Mg) & 30 & 100 & $\mathrm{mg} / \mathrm{l}$ \\
\hline 11. & Nitrate (as NO3) & 45 & No Relaxation & $\mathrm{mg} / \mathrm{l}$ \\
\hline 12. & Sulphate (as SO4) & 200 & 400 & $\mathrm{mg} / \mathrm{l}$ \\
\hline 13. & $\begin{array}{l}\text { Total alkalinity as } \\
\text { calcium carbonate }\end{array}$ & 200 & 600 & $\mathrm{mg} / \mathrm{l}$ \\
\hline 14. & $\begin{array}{l}\text { Total hardness } \\
\text { (as CaCO3) }\end{array}$ & 200 & 600 & $\mathrm{mg} / \mathrm{l}$ \\
\hline 15. & Zinc (as Zn) & 5 & 15 & $\mathrm{mg} / \mathrm{l}$ \\
\hline
\end{tabular}

Note: only parameters having interest are taken from IS 10500:2012 and given in the table-2

Table 3:

\begin{tabular}{|l|l|l|l|l|}
\hline Sr. & $\begin{array}{l}\text { Parameters } \\
\text { Concerning Toxic } \\
\text { Substances }\end{array}$ & $\begin{array}{l}\text { Requirement } \\
\text { (Acceptable Limit) }\end{array}$ & $\begin{array}{l}\text { Permissible Limit in } \\
\text { the Absence of } \\
\text { Alternative Source }\end{array}$ & Unit \\
\hline 1. & Cadmium (as Cd) & 0.003 & No Relaxation & $\mathrm{mg} / \mathrm{l}$ \\
\hline 2. & Lead (as Pb) & 0.01 & No Relaxation & $\mathrm{mg} / \mathrm{l}$ \\
\hline 3. & Mercury (as Hg) & 0.001 & No Relaxation & $\mathrm{mg} / \mathrm{l}$ \\
\hline 4. & Molybdenum (as Mo) & 0.07 & No Relaxation & $\mathrm{mg} / \mathrm{l}$ \\
\hline 5. & Nickel (as Ni) & 0.02 & No Relaxation & $\mathrm{mg} / \mathrm{l}$ \\
\hline 6. & Total arsenic (as As) & 0.01 & 0.05 & $\mathrm{mg} / \mathrm{l}$ \\
\hline 7. & Total chromium (as Cr) & 0.05 & No Relaxation & $\mathrm{mg} / \mathrm{l}$ \\
\hline
\end{tabular}

Note: only parameters having interest are taken from IS 10500:2012 and given in the table-3.

2.0 Materials and Methods:

Methods used to analyze physicochemical parameters in ground water are prescribed in American public health association (APHA)[20] and Bureau of Indian standard (BIS). Physico-chemical Parameters included for the assessment of ground water quality are $\mathrm{pH}$, Total dissolve solids, Electrical conductivity, Temperature, Total hardness, Calcium, Magnesium,
Sulphate, Fluoride, Alkalinity, Chloride, Nitrate, Nitrite, Potassium and Sodium.

Grab Sampling is the most used technique for groundwater samples in which single samples collected from a specific site in a short period of time, generally from few seconds to minutes thus a single sample represent the whole quality of water. 
Table 4: Test Parameters with Equipment, Glassware, RM and Reagents.

\begin{tabular}{|c|c|c|}
\hline Test Parameter & Equipment/ Glass wares & Reference Material/Reagents \\
\hline Calcium (as Ca) & Burette/pipette & Calcium \\
\hline Chloride (as Cl) & Burette/pipette & Sodium Chloride \\
\hline Colour & Nessler Tubes & $\begin{array}{l}\text { Potassium chloroplatinate, } \\
\text { Cobaltous chloride }\end{array}$ \\
\hline Magnesium (as Mg) & Burette/pipette & Magnesium \\
\hline Odour & Thermometer/ Erlenmeyer flask & Odour free water \\
\hline $\mathrm{pH}$ & pH Meter & pH Buffer \\
\hline Taste & Erlenmeyer flask & Sodium Chloride \\
\hline Total Alkalinity (as $\mathrm{CaCO}_{3}$ ) & Burette/pipette & Sodium Carbonate \\
\hline Total Dissolved Solids & Balance/Oven & NA \\
\hline Total Hardness (as $\mathrm{CaCO}_{3}$ ) & Burette/pipette & Calcium carbonate \\
\hline Turbidity & Turbidity Meter & $\begin{array}{l}\text { Hydrazine sulfate, } \\
\text { hexamethylenetatraamine }\end{array}$ \\
\hline Fluoride (as F) & Spectrophotometer & Fluoride \\
\hline Iron (as Fe) & ICP/AAS/Spectrophotometer & Iron \\
\hline Sulphate (as $\mathrm{SO}_{4}$ ) & Spectrophotometer & Sulphate \\
\hline Arsenic (as As) & ICP/AAS & Arsenic \\
\hline Nitrate (as $\mathrm{NO}_{3}$ ) & Spectrophotometer & Nitrate \\
\hline Total Coliform & Incubator/Autoclave & Reference culture \\
\hline E-coli & Incubator/Autoclave & Reference culture \\
\hline
\end{tabular}

Test methods to analyze above mentioned parameters are followed from available Indian standard (IS 3025) and American public health association (APHA $23^{\text {rd }}$ Edition), 2017 by using equipment/glassware and reference materials/reagents given in table-4.[21]

\section{CONCLUSION}

The quality of groundwater is being deteriorate day by day due to over exploitation of groundwater. the rate of the of underground water for domestic, Industrial, Agricultural and other purposes is more against the recharge or replenish of groundwater. Increasing desertification and loss of green cover are reducing the land's capacity to recharge groundwater aquifer and regional water tables. Extensive groundwater extraction contributes to the decline the groundwater quality and loss of vegetation cover also.

It is required to recharge the groundwater resources and to maintain the sustainable approach for groundwater to maintain the difference of recharge or replenish of groundwater and the pumping of groundwater. It is also advised to monitor the groundwater quality on regular intervals to know about the current status of groundwater quality. It is individuals and community's responsibility to minimize the water pollution by adopting sustainable approaches for groundwater management.

\section{REFERENCES}

1. Agarwal, M., Singh, M. and Hussain, J. (2019). Assessment of groundwater quality with special emphasis on nitrate contamination in parts of Gautam Budh Nagar district, Uttar Pradesh, India. Acta Geochimica.

2. Sharma, B., Agrawal, J. and Gupta, A. (2011). Emerging Challenge: Fluoride Contamination in Groundwater in Agra District, Uttar Pradesh. ASIAN J. EXP. BIOL.SCI., VOl 2 (1). 
3. Yadav,K., Gupta,N., Kumar,V., Arya,S. and Singh,D. (2012). Physico Chemical Analysis of Selected Ground Water Samples of Agra City. Recent Research in Science and Technology, 4(11), pp. 51-54.

4. Jha, S., Nayak, A. and Sharma, Y. (2009). Potential fluoride contamination in the drinking water of Marks Nagar, Unnao district, Uttar Pradesh, India. Environmental Geochemistry and Health, 32(3), pp.217-226.

5. Kumar, N., Sinha, D. (2010). Drinking Water Quality Management Through Correlation Studies Among Various Physico-Chemical Parameters-A Case Study. International Journal of Environmental Sciences Volume 1, No 2, pp.253-259.

6. Hossain, D., Islam, M., Sultana, N. and Tusher, T. (2013). Assessment of Iron Contamination in Groundwater at Tangail Municipality, Bangladesh. Journal of Environmental Science and Natural Resources, 6(1), pp.117-121.

7. Kumar, S. and Nagaraja, B. (2010). Environmental impact of leachate characteristics on water quality. Environmental Monitoring and Assessment, 178(1-4), pp.499-505.

8. Singh., Ajai. (2012-13). District Groundwater brochure Agra District, Uttar Pradesh.

9. Chakrabarty, S. and Sarma, H. (2010). Heavy metal contamination of drinking water in Kamrup district, Assam, India. Environmental Monitoring and Assessment, 179(1-4), pp.479-486.

10. Chaudhary, V., Kumar, M., Sharma, M., \& Yadav, B. (2009). Fluoride, boron and nitrate toxicity in ground water of northwest Rajasthan, India. Environmental Monitoring And Assessment, 161(1-4), 343-348.

11. Gupta, M., Singh, V., Rajwanshi, P., Agarwal, M., Rai, K., Srivastava, S., Shrivastav, R. and Dass, S. (1999). Groundwater Quality Assessment of Tehsil Kheragarh, Agra (India) with Special Reference to Fluoride. Environmental Monitoring and Assessment, 59(3), pp.275-285.

12. K. Yogendra and Puttaiah, E. (2008). Determination of Water Quality Index and
Suitability of an Urban Waterbody in Shimogha Town, Karnataka. The World Lake Conference, pp. 342-346.

13. Vasanthavigar, M., Srinivasamoorthy, K., Vijayaragavan, K., Rajiv Ganthi, R., Chidambaram, S., \& Anandhan, P. et al. (2010). Application of water quality index for groundwater quality assessment: Thirumanimuttar sub-basin, Tamilnadu, India. Environmental Monitoring And Assessment, 171(1-4), 595-609. doi: 10.1007/s10661-0091302-1

14. Sharma, A. (2015). Physico-Chemical Analysis of Tap Water of Chandigarh (UT) India. Int J Curr Sci, 14: pp. 51-54.

15. Fallahzadeh, R., Ghaneian, M., Miri, M., \& Dashti, M. (2017). Spatial analysis and health risk assessment of heavy metals concentration in drinking water resources. Environmental Science And Pollution Research, 24(32), 24790-24802.

16. Salve, P., Maurya, A., Kumbhare, P., Ramteke, D. and Wate, S. (2008). Assessment of Groundwater Quality with Respect to Fluoride. Bulletin of Environmental Contamination and Toxicology, 81(3), pp.289-293.

17. Dhawle P.G, Ghyare B.P. (2015). Assessment of Physico-Chemical Status of Water in Pus Dam of Pusad Tahsil. Journal of Natural Sci Research, Vol.5, No.9, pp.1-5.

18. Deshmukh, K. (2011). Assessment of Ground Water Quality in Sangamner Area for Sustainable Agricultural Water Use Planning. Int. J. Chem. Sci, 9(3), pp.1486-1500.

19. IS 10500: 2012. Drinking Water Specification, Bureau Of Indian Standards, Manak Bhavan, New Delhi.

20. American Public Health Association (APHA). $23^{\text {rd }}$ Edition (2017).

21. State profile, Ground water scenario of Uttar Pradesh UP, Central Ground water Board (CGWB), Ministry of Water Resources, Govt. of India. 